San Jose State University

SJSU ScholarWorks

Master's Projects

Master's Theses and Graduate Research

Spring 5-2018

\title{
HUD’s Transitional Housing Unit Program's Role in the Santa Clara County Community Plan to End Homelessness
}

\author{
Emilie Thorburn-Quihuis \\ San Jose State University
}

Follow this and additional works at: https://scholarworks.sjsu.edu/etd_projects

Part of the Policy Design, Analysis, and Evaluation Commons, Public Administration Commons, Social Policy Commons, and the Social Welfare Commons

\section{Recommended Citation}

Thorburn-Quihuis, Emilie, "HUD's Transitional Housing Unit Program's Role in the Santa Clara County Community Plan to End Homelessness" (2018). Master's Projects. 588.

DOI: https://doi.org/10.31979/etd.yby3-dxsu

https://scholarworks.sjsu.edu/etd_projects/588

This Master's Project is brought to you for free and open access by the Master's Theses and Graduate Research at SJSU ScholarWorks. It has been accepted for inclusion in Master's Projects by an authorized administrator of SJSU ScholarWorks. For more information, please contact scholarworks@sjsu.edu. 


\title{
HUD's Transitional Housing Unit Program's Role in the Santa Clara County Community Plan to End Homelessness
}

\author{
By \\ Emilie Thorburn-Quihuis \\ A Thesis Quality Research Paper \\ Submitted in Partial Fulfillment of the \\ Requirements for the \\ Master's Degree \\ In \\ PUBLIC ADMINISTRATION
}

Prof. Frances Edwards. Ph.D.

Advisor

The Graduate School

San Jose State University

May, 2018 


\section{Table of Contents}

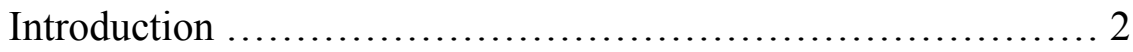

Literature Review $\ldots \ldots \ldots \ldots \ldots \ldots \ldots \ldots \ldots \ldots \ldots \ldots \ldots \ldots \ldots . \ldots . \ldots \ldots$

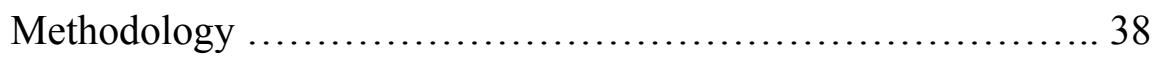

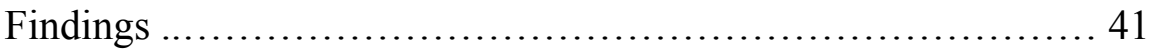

Analysis .............................................. 50

Conclusion and Recommendation ............................. 56

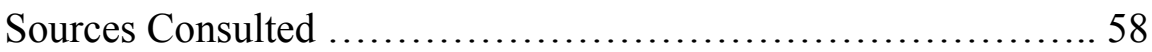




\section{INTRODUCTION}

\section{Problem Statement}

Counties in California invest local, state, and federal funds to try to end homelessness. At present the homeless numbers in Santa Clara County are among the highest in the U.S. at 6,556, with 33\% of those being chronically homeless. (County of Santa Clara, 2015, p. 16). Using process evaluation to compare permanent housing and shelter demographics and recurrence rates, how is the federal Housing and Urban Development's (HUD) Transitional Housing Units Program (THU) in Santa Clara County meeting the goals of the county’s Community Plan to End Homelessness 2015-2020 (2013)?

\section{Defining Homelessness}

Types and definitions of homelessness vary by organization. The National Coalition of Homelessness (NCH) (2014) discusses three types of homelessness: chronic, transitional, and episodic. Chronic homelessness is described as "likely to be entrenched in the shelter system and for whom shelters are like long-term housing rather than an emergency arrangement" (web). Chronically homeless individuals are likely to be older, "hard-core unemployed" (National Coalition of Homelessness, 2014, web), and often suffer from disabilities and substance abuse. Rickards, McGraw, Araki, Casey, High, Hombs and Raysor (2010) cite the Department of Health and Human Services, Veterans' Affairs, and HUD definition of chronic homelessness as "the circumstance whereby an unaccompanied individual with a disabling condition... has either been continuously homeless for a year or more or has had at least four homeless episodes during the last 
three years" (p. 151). In its 2017 Point in Time Survey, Santa Clara County defines chronically homeless as someone who has "experienced homelessness for a year or longer, or who has experienced at least four episodes of homelessness in the last three years, and also has a long-term disabling condition" (Santa Clara County, 2017, p. 33).

Transitional homeless individuals "generally enter the shelter system for only one stay and for a short period" (National Coalition for the Homeless, 2014). They move in and out of shelters and homelessness, and are likely to be younger, become homeless after a catastrophic event, and make up the majority of homeless persons because of their higher turnover rate.

Episodic homeless are those who move in and out of shelters and homelessness and are also likely to be younger (National Coalition for the Homeless, 2014).

Alternately, HUD recognizes four types of homelessness: "Individuals and families who lack a fixed, regular, and adequate nighttime residence and includes a subset for an individual who is exiting an institution where he or she resided for 90 days or less and who resided in an emergency shelter or a place not meant for human habitation immediately before entering that institution;" "Individuals and families who will imminently lose their primary nighttime residence;" "Unaccompanied youth and families with children and youth who are defined as homeless under other federal statutes who do not otherwise qualify as homeless under this definition;" or "individuals and families who are fleeing, or are attempting to flee, domestic violence, dating violence, sexual assault, stalking, or other dangerous or life-threatening conditions that relate to violence against the individual or a family member" (HUD, 2013, p. 1-2). 


\section{Measuring Homelessness}

The Point-in-Time survey is a census conducted at the end of January every two years across the country to "conduct comprehensive counts of their [communities'] populations to measure the prevalence of homelessness in their communities." Homeless individuals counted are found in emergency shelters and transitional housing, living on the streets, in their cars, on abandoned properties, as well as other places not appropriate for human habitation. HUD requires every jurisdiction receiving federal funding to provide homeless housing and services to participate and report their findings, which are the country's primary source of sheltered and unsheltered homeless population data. In Santa Clara County and the City of San Jose, the biennial survey is conducted in partnership with the nonprofit Applied Survey Research (ASR) (County of Santa Clara, 2015, p. 15).

\section{Homelessness in Santa Clara County}

In the 2015 homeless survey, the county's counts found approximately 1,929 sheltered homeless individuals and 4,627 unsheltered individuals. Of the sheltered individuals, $12 \%$ lived in emergency shelters, $17 \%$ in transitional housing, and less than $1 \%$ in Safe Haven, a program formerly eligible under the Continuum of Care program. Of the unsheltered individuals, $30 \%$ were living on the streets, $4 \%$ in abandoned buildings, $23 \%$ in vehicles such as cars or RVs, and 14\% in encampment areas. An assessment of homelessness counts from 2009 to 2015 found that homelessness was on a decline, but increased in 2017. There were 2,103 sheltered homeless individuals in 2009 , totaling 7,086, a drop of over 500 people by 2015 (County of Santa Clara, 2015), but increased by 
Table 1: Santa Clara County Homeless Statistics

\begin{tabular}{|c|c|c|c|c|c|}
\hline & 2009 & 2011 & 2013 & 2015 & 2017 \\
\hline $\begin{array}{l}\text { Total } \\
\text { Homeless In } \\
\text { SCC }\end{array}$ & 7,086 & 7,067 & 7,631 & 6,556 & 7,394 \\
\hline $\begin{array}{l}\text { Sheltered in } \\
\text { county }\end{array}$ & $2,103(30 \%)$ & $1,898(27 \%)$ & $1,957(26 \%)$ & $1,929(29 \%)$ & $1,946(26 \%)$ \\
\hline $\begin{array}{l}\text { Total } \\
\text { Number of } \\
\text { Chronically } \\
\text { Homeless }\end{array}$ & 979 & 2,520 & 2,518 & 2,169 & 2,097 \\
\hline $\begin{array}{l}\text { First Time } \\
\text { homeless }\end{array}$ & $\mathrm{n} / \mathrm{a}$ & $48 \%$ & $46 \%$ & $33 \%$ & $41 \%$ \\
\hline Individuals & 7,086 & 7,067 & 7,631 & 6,556 & 7,394 \\
\hline Families & $\mathrm{n} / \mathrm{a}$ & $\mathrm{n} / \mathrm{a}$ & 349 & 266 & 294 \\
\hline $\begin{array}{l}\text { Individual } \\
\text { Family } \\
\text { Members }\end{array}$ & $\mathrm{n} / \mathrm{a}$ & $\mathrm{n} / \mathrm{a}$ & 1,067 & 908 & 1,075 \\
\hline Veterans & 866 & 667 & 718 & 703 & 660 \\
\hline
\end{tabular}

Source: Santa Clara County, 2017, p. 11, 12, 21, 44.

over 800 in 2017 (County of Santa Clara, 2017). The majority of the county's homeless live in the City of San Jose, with 4,034 in 2011, 4,770 in 2013, 4,063 in 2015 and 4,350 in 2017 (City of San Jose, 2017, p. 11). It is noted that a change in the count from 2013 to 2015 may be attributed to cold weather bed programs opening, most of them in San Jose, as well as a number of transitional housing units becoming permanent housing units.

(County of Santa Clara, 2015). 
Table 2: Usual Places to Sleep

\begin{tabular}{|l|l|l|l|l|}
\hline & 2011 & 2013 & 2015 & 2017 \\
\hline $\begin{array}{l}\text { Emergency, } \\
\text { transitional, or } \\
\text { other shelter }\end{array}$ & $27 \%$ & $33 \%$ & $34 \%$ & $36 \%$ \\
\hline $\begin{array}{l}\text { Outside, streets, } \\
\text { parks, or } \\
\text { encampments }\end{array}$ & $34 \%$ & $42 \%$ & $36 \%$ & $35 \%$ \\
\hline $\begin{array}{l}\text { Structure or } \\
\text { indoor area not } \\
\text { meant for } \\
\text { sleeping }\end{array}$ & $15 \%$ & $9 \%$ & $15 \%$ & $14 \%$ \\
\hline motel/hotel & $8 \%$ & $5 \%$ & $7 \%$ & $8 \%$ \\
\hline $\begin{array}{l}\text { Vehicle (car, } \\
\text { van, RV, } \\
\text { camper) }\end{array}$ & $11 \%$ & $10 \%$ & $8 \%$ & $8 \%$ \\
\hline
\end{tabular}

Source: Santa Clara County, 2017, p.22

\section{Background}

An individual or family suffering from addiction, mental or physical health issues,

domestic violence, unemployment, or lack of affordable housing can be at imminent risk

of becoming homeless, and often resources and public aid are unknown to the individuals and families at risk, or difficult to find and navigate. In Santa Clara County, homelessness is exacerbated by heightened cost of living, living wage, wage gap, and rent rates (Thomas, 2017).

In 2014, the organization Destination: Home organized the Community Plan to End Homelessness 2015-2020 as a "community wide roadmap to end homelessness for 
the next five years, and is proposed to guide government, nonprofits and other community members as they make decisions about funding, programs, priorities and needs" (Destination: Home, 2016, p. 2), with the goal of "guid[ing] governmental actors, nonprofits, and other community members as they make decisions about funding, programs, priorities, and needs" (Destination: Home, 2016, p. 2). This plan acknowledges that many people living in Santa Clara County are an illness, accident, or missed paycheck away from becoming homeless, and states that, "There are many ways someone can become homeless and only one way to really solve it. Homelessness doesn't end when we clear out an encampment or when we hand out blankets. Homelessness ends when everyone has a home" (Destination: Home, 2016, p. 3), and focuses on the goals to “disrupt systems, build the solution, and serve the person" (Destination: Home, 2016, p. 3) by changing the way governments, communities, businesses and organizations view homelessness, creating new housing solutions, and providing unique and personalized approaches and solutions for each population and need. (Destination: Home, 2014, p. 2).

The goals of The Plan are to be achieved through three strategies: to "disrupt the system" by "develop[ing] strategies and innovative prototypes that transform the systems related to housing homeless people," to "build the system" by "secur[ing] the funding needed to provide 6,000 housing opportunities with services to those who are homeless and those at risk of homelessness," and to "serve the person" by "adopt[ing] an approach that recognizes the need for client-centered strategies with different responses for different levels of need and different groups, targeting resources to the specific individual or household" (Keene, 2016, p. 3). 
There are three target population groups within The Plan, and it aims to house 2,518 chronically homeless individuals, 718 veterans, and at least 233 children, youth and families. These specific numerical goals are based on Santa Clara County's 2013 Point-in-Time count, which found these exact numbers for chronically homeless and veterans; 1,266 unaccompanied youth under 25 years were counted, of which 164 were minors, as well as 1,067 homeless individuals in 349 families with at least one child under 18 years of age (Destination: Home, 2014).

The Community Plan to End Homelessness, as a project of Destination: Home, is managed by the organization's team. Its funding comes from the Silicon Valley Community Foundation (A. Herrera, Destination: Home, personal communication, August 22, 2017).

In Santa Clara County, agencies with THU programs include Bill Wilson Center, LifeMoves, Pathway Society, Home First and Salvation Army. The Bill Wilson Center in San Jose offers a wide range of services, including transitional housing. The Transitional Housing Placement Program offers services for youth ages 16 to 18 "in dependency, either through foster care or juvenile justice" (Bill Wilson Center, n.d.). This program provides housing and skills coaching with the goal of independent living for youth who risk aging out of foster care or the juvenile justice system without having been taught how to take care of themselves. The Transitional Housing Program, for youth and young adults ages 18 through 24 , including young parents with children, provides transitional 
housing in shared, supervised apartments or houses, during which they receive counseling, independent living skills training, parenting classes and employment services.

LifeMoves, with several locations in Santa Clara County and San Mateo County, also offers a range of services, which includes transitional housing at three locations in San Jose. Montgomery Street Inn offers transitional housing programs for single men, as well as two veteran programs and hosted cold weather beds on county Inclement Weather Nights. Julian Street Inn offers co-ed mental health services, and Georgia Travis House is open to single women, and men or women with children under the age of 18 (LiveMoves, 2018).

Pathway Society is a transitional program for recovering drug and alcohol addicts. The agency has two rehabilitation and detoxification sites, and offers transitional, independent housing at an undisclosed location once rehab programs have been completed (Pathway Society, 2014). 
Table 3: Goal \#1: Disrupt the System

\begin{tabular}{|c|c|c|c|}
\hline $\begin{array}{l}\text { What We Are } \\
\text { Doing }\end{array}$ & How We Will Do It & 2015 & 2020 \\
\hline \multirow[t]{4}{*}{$\begin{array}{l}\text { The Best Homeless } \\
\text { System of Care }\end{array}$} & $\begin{array}{l}\text { Coordinate housing and } \\
\text { services to connect each } \\
\text { individual with the right } \\
\text { housing solution }\end{array}$ & $\begin{array}{l}\text { Homeless people may call } \\
\text { many providers and sit on } \\
\text { several waiting lists before } \\
\text { they get housed and many } \\
\text { families become homeless } \\
\text { when it could be avoided }\end{array}$ & $\begin{array}{l}\text { People who are homeless } \\
\text { or at risk of homelessness } \\
\text { get connected directly to } \\
\text { the } \\
\text { right resource for them }\end{array}$ \\
\hline & $\begin{array}{l}\text { Respond to system } \\
\text { barriers and service gaps by } \\
\text { making the best use of } \\
\text { existing assets }\end{array}$ & $\begin{array}{l}\text { There are many homeless } \\
\text { programs and responses in } \\
\text { this community, but no } \\
\text { great way of knowing } \\
\text { what works } \\
\text { best, with lots of people } \\
\text { still living outside }\end{array}$ & $\begin{array}{l}\text { Community-wide, } \\
\text { outcome- } \\
\text { based decisions about the } \\
\text { best programs and } \\
\text { structures to meet } \\
\text { community } \\
\text { needs are made and } \\
\text { implemented }\end{array}$ \\
\hline & $\begin{array}{l}\text { Partner across public and } \\
\text { private sectors to improve } \\
\text { systemic coordination }\end{array}$ & $\begin{array}{l}\text { The private and public } \\
\text { sectors } \\
\text { operate independently, } \\
\text { resulting in a patchwork } \\
\text { of funding, priorities, and } \\
\text { outcomes }\end{array}$ & $\begin{array}{l}\text { Private sector and public } \\
\text { sector funding is mutually } \\
\text { supportive, creating a } \\
\text { system } \\
\text { of care that's internally } \\
\text { consistent }\end{array}$ \\
\hline & Increase provider capacity & $\begin{array}{l}\text { Homeless providers } \\
\text { want to end homelessness, } \\
\text { but may not have the } \\
\text { resources to do that }\end{array}$ & $\begin{array}{l}\text { All homeless providers } \\
\text { have sufficient resources } \\
\text { to successfully implement } \\
\text { programs that end } \\
\text { homelessness }\end{array}$ \\
\hline
\end{tabular}

Source: Community Plan to End Homelessness 2015-2020 (2014, p. 7). 
Table 4: Goal \#2: Build the System:

\begin{tabular}{|c|c|c|c|}
\hline What We Are Doing & How We Will Do It & 2015 & 2020 \\
\hline \multirow[t]{2}{*}{$\begin{array}{l}\text { Create } \\
\text { New } \\
\text { Homes } \\
\text { And } \\
\text { Opportunities } \\
\text { For Homeless } \\
\text { Men, Women, } \\
\text { And Children }\end{array}$} & $\begin{array}{l}\text { Create } 6,000 \text { housing } \\
\text { opportunities }\end{array}$ & $\begin{array}{l}\text { There are } \\
\text { approximately } \\
6,000 \text { people in our } \\
\text { three target } \\
\text { populations who do } \\
\text { not have homes }\end{array}$ & $\begin{array}{l}\text { People who are } \\
\text { homeless } \\
\text { have } 6,000 \text { more } \\
\text { housing } \\
\text { opportunities available } \\
\text { to } \\
\text { them }\end{array}$ \\
\hline & $\begin{array}{l}\text { Fund supportive } \\
\text { services for the new } \\
\text { housing opportunities }\end{array}$ & $\begin{array}{l}\text { People who are } \\
\text { homeless, even if they } \\
\text { have housing, } \\
\text { often cannot maintain } \\
\text { it without case } \\
\text { management, health } \\
\text { care, and financial } \\
\text { services }\end{array}$ & $\begin{array}{l}\text { Each of the } 6,000 \text { new } \\
\text { tenants has access to the } \\
\text { services that will allow } \\
\text { him or her to maintain } \\
\text { housing }\end{array}$ \\
\hline
\end{tabular}

Source: Community Plan to End Homelessness 2015-2020 (2014, p. 6).

Home First has multiple transitional housing programs throughout the county:

Boccardo Reception Center in San Jose provides both emergency shelter and transitional housing with critical services; Sobrato Family Living Center in Santa Clara gives mental health services, employment placement, emergency shelter, transitional housing and support to families, with a focus on veterans and their families, and an outreach program for homeless encampments and county Inclement Weather Nights; and Sobrato House Youth Center in downtown San Jose is operated for former foster youth who have aged out of the system (Destination: Home, n.d.). 
Table 5: Goal \#3: Serve the Person

\begin{tabular}{|c|c|c|c|}
\hline What We Are Doing & $\begin{array}{l}\text { How We Will Do } \\
\text { It }\end{array}$ & 2015 & 2020 \\
\hline \multirow[t]{3}{*}{$\begin{array}{l}\text { Different } \\
\text { Responses } \\
\text { For } \\
\text { Different } \\
\text { Levels Of } \\
\text { Need }\end{array}$} & $\begin{array}{l}\text { Provide } \\
\text { permanent } \\
\text { supportive } \\
\text { housing to } \\
\text { end chronic } \\
\text { homelessness }\end{array}$ & $\begin{array}{l}\text { Many disabled people } \\
\text { who have lived outside, } \\
\text { sometimes for years, } \\
\text { need } \\
\text { housing that responds to } \\
\text { their conditions }\end{array}$ & $\begin{array}{l}\text { Chronically homeless } \\
\text { people } \\
\text { can access permanent } \\
\text { supportive housing with } \\
\text { intensive case management } \\
\text { and wrap-around services }\end{array}$ \\
\hline & $\begin{array}{l}\text { Expand rapid } \\
\text { rehousing } \\
\text { resources to } \\
\text { respond to } \\
\text { episodic } \\
\text { homelessness }\end{array}$ & $\begin{array}{l}\text { Some people in our } \\
\text { Community experience } \\
\text { repeated bouts of } \\
\text { homelessness and are } \\
\text { not able to stabilize } \\
\text { with the resources } \\
\text { available to them }\end{array}$ & $\begin{array}{l}\text { Households with barriers } \\
\text { to housing can access a } \\
\text { temporary housing subsidy } \\
\text { and step down services } \\
\text { that are structured to end } \\
\text { homelessness for that } \\
\text { household for good }\end{array}$ \\
\hline & $\begin{array}{l}\text { Prevent } \\
\text { homelessness } \\
\text { before it happens }\end{array}$ & $\begin{array}{l}\text { There are not enough } \\
\text { resources available } \\
\text { to help people avoid } \\
\text { homelessness, or avoid } \\
\text { homelessness again }\end{array}$ & $\begin{array}{l}\text { Households at risk of } \\
\text { homelessness have access } \\
\text { to homeless prevention } \\
\text { resources: housing stability } \\
\text { services, emergency } \\
\text { rental assistance, financial } \\
\text { literacy, \& landlord/tenant } \\
\text { assistance and employment } \\
\text { assistance and employment } \\
\text { support services: child care, } \\
\text { transportation, job training } \\
\& \\
\text { placement }\end{array}$ \\
\hline
\end{tabular}

Source: Community Plan to End Homelessness 2015-2020 (2014, p. 7).

The Emmanuel House in downtown San Jose, run by the Salvation Army, is open

to the public daily for lunch and dinner, and has a religiously led, sober living 
environment transitional program for men who can pay program fees (Salvation Army, n.d.).

The THU program and these agencies meet the goals of the Community Plan to End Homelessness in Santa Clara County, to disrupt the system, build the system, and serve the person, by offering services and transitional housing to each of its target population groups, by agencies working with the county to secure increased funding, and with person-specific services such as employment assistance, counseling, and drug and alcohol rehabilitation.

\section{Implementation}

The Community Plan to End Homelessness's three goals can be broken down into three actions: managing and ending homelessness through the Housing First plan; providing different housing types to meet the needs of each population; and preventing and addressing obstacles to permanent housing by addressing unique challenges.

The Housing First plan focuses on providing homeless individuals with housing before providing the services necessary to maintain their housing, and is "consistent with what most people experiencing homelessness want and seek help to achieve" (Destination: Home, 2018). An example of this approach is providing methamphetamine users with safe long-term housing before requiring them to go into drug treatment to get clean. The statement "unique approaches to unique populations" describes the creation of different housing types, such as converted motels, small houses, and permanent supportive housing in an effort to meet the needs of each population of homeless 
individuals and families being served (Santa Clara County, p. 8). Lastly, the survey outline states that $64 \%$ of individuals interviewed reported a unique challenge in looking for permanent housing, such as mental illness, substance abuse, chronic illness, or a disability. The plan works to meet the needs of those facing these challenges by providing services such as rent and mortgage assistance, mental health services, employment assistance, and drug and alcohol counseling (Santa Clara County, p. 9).

Santa Clara County is a recipient of HUD's federal formula grant funds from the Community Development Block Grant (CDBG) and Home Investment Partnerships (HOME). By federal law, each jurisdiction receiving these grants is required to submit an Annual Action Plan to HUD, listing priorities and strategies for their use. Santa Clara County's submission for the fiscal year of 2017-2018 lists the following goals in its Annual Action Plan:

"1. Assist in the creation and preservation of affordable housing opportunities for low income and special needs households. 2. Support activities to end homelessness. 3. Support activities that provide community services to low income and special needs households. 4. Support activities that strengthen neighborhoods. 5. Promote fair housing choice (Office of Supportive Housing, 2018, p. 2-3)."

Two of the listed Action Plans include "addressing the emergency shelter and transitional housing needs of homeless persons" and "helping homeless persons (especially chronically homeless individuals and families, families with children, veterans and their families, and unaccompanied youth) make the transition to permanent housing and independent living, including shortening the period of time that individuals 
and families experience homelessness, facilitating access for homeless individuals and families to affordable housing units, and preventing individuals and families who were recently homeless from becoming homeless again," and granted federal money to San Jose Family Shelter and Bridges AfterCare Program, and San Jose Family Shelter, Bridges AfterCare, and LifeMoves Opportunity Services Center respectively (Office of Supportive Housing, 2018, p. 37).

One of the Action Plan's "proposed substantial amendments" was to "Amend Project No. CDBG-18-03 County OSH Multi-family Acquisition and/or Rehabilitation to include rehabilitation of Emergency Shelters and Transitional Housing (ES/TH) and increase funding from $\$ 35,237$, to $\$ 365,000$, using un-programmed $\mathrm{CDBG}$ revolving loan funds" (Office of Supportive Housing, p. 4).

Direct references to the county's Community Plan and its goals are made, and the action plan references the same target populations.

Community Plan has rallied local nonprofits and corporations, creating new programs, expanding existing ones, and generating funding for low-income housing developments and refurbishing of unused units. New developments in progress include increases in HUD-Veterans Affairs Supportive Housing (HUD VASH) vouchers use and an increase in housed formerly homeless veterans (The Health Trust, 2017) and expansion of the Landlords Incentive Program (cite: Health Trust). In 2016 Measure A passed, which provides $\$ 950$ million for development and construction of new supportive and rapid re-housing units (cite: Health Trust)- “A year later, they’ve already funded the 
first six projects—all focused on new extremely low-income affordable and supportive housing" (Loving, 2018).

Emergency Assistance Network (EAN) assists with keeping units or rehousing; "a collection of local nonprofits that help low income residents pay for rent and other housing costs to avoid eviction and homelessness" (The Health Trust, 2017, p. 5) and Homelessness Prevention \& Rapid Re-Housing System: "This system will be responsible for coordinating all of the homelessness prevention efforts throughout the county. It will allow results to be tracked across the county, with shared outcomes and metrics, including how many families our system will keep from becoming homeless and how many families will be quickly moved from streets to homes" (The Health Trust, 2017, p. $5)$.

On March 26, 2018, Cisco announced \$50 million donation to Destination: Home over the next five years. An initial $\$ 20$ million was donated, with the message that the funding was meant to "invigorate Destination: Home's efforts to achieve its five-year plan to end homelessness" (Dickey, 2018, web).

The City of San Jose's short- and long-term actions to assisting while homeless and after housed include cooling and warming centers, inclement weather beds, faith-based temporary shelters, hotel/motel supportive housing, tenant-based rental assistance, and transition-in-place programs (Morales-Ferrand, 2016). 


\section{History of Housing Laws}

California's legislation regarding homeless communities has historically been hostile; from Anti-Vagrancy Acts in 1855 targeting Mexican-Americans and the 1867 Order No. 873 "To Prohibit Street Begging, and to Restrain Certain Persons from Appearing in Streets and Public Places" to San Francisco's 2010 "sit-lie" law, "Promotion of Civil Sidewalks," prohibiting sitting or lying on public sidewalks "with exceptions for certain activities deemed lawful" and the 2016 Proposition Q, the "Promotion of Safe and Open Sidewalks" law which authorized city agencies to remove tents from public thoroughfares without offering new funding for supplementary housing or shelters (Bloomberg, 2017).

Cities' varied approaches to the increasing homeless communities have included the "shelter-bed-and-a-sandwich" approach, with the hopes that the offer of a place to sleep would encourage homeless individuals to work harder. (Fagan, 2016). Fagan describes how major cities like San Francisco and New York "learned that without dealing with the underlying factors that cause the most acutely troubles [sic] people to lose their housing- mental illness, substance abuse, disabilities and joblessnesstemporary shelters accomplish little" and that "that realization led to another: doing more than just providing a cot for the night is incredibly expensive." Reagan's "Reaganomics" approach to homelessness included the cutting of federal spending on subsidized housing and funding for HUD, and the suggestion that churches and synagogues take in homeless families (Roberts, 2016). 


\section{History of THU}

Transitional Housing Units (THU), also known as Supportive Housing programs, is a component of HUD's Continuum of Care (CoC), a program that provides services to homeless individuals and families such as housing, planning, connection with resources, data collection, and community coordination. The CoC's funds are allocated to five programs: permanent housing, transitional housing, supportive services, Homeless Management Information System (HMIS), and homelessness prevention. (HUD Exchange, 2018). The CoC's definition of THU describes them as “designed to provide homeless individuals and families with the interim stability and support to successfully move to and maintain permanent housing," and states that THU placements may last up to 24 months. Program participants are required to receive a lease, sublease, or occupancy agreement (HUD Exchange, 2018). The Code of California Regulations $\S 3378.7$ states that THU must provide residents with a "general population" setting, last up to 24 months, and include, but not be limited to, "conflict resolution, anger control, substance abuse education, communication skills, individual counseling, educational skills, and group exercises" (California Code of Regulations, 2017).

THUs were originally created by HUD after the establishment of the McKinney-Vento Act. In the 1980s, responses to increasing homelessness were local, as the Reagan administration did not view the issue as one requiring federal intervention. As advocates pushed for federal assistance, the Homeless Persons' Survival Act of 1986 was introduced, which offered emergency relief and preventive measures, and long term solutions; the Homeless Eligibility Clarification Act of 1986 removed permanent address 
requirements for services such as Supplemental Security Income, Veterans Benefits, Food Stamps and Medicaid; the Homeless Housing Act created the HUD-administered Emergency Shelter Grant program and a transitional housing demonstration program; and the Urgent Relief for the Homeless Act, which included Title I of the Homeless Person's Survival Act, emergency provisions which included transitional housing, passed in 1987.

Eventually named the McKinney-Vento Act, it contained Title IV, which "authorizes the emergency shelter and transitional housing programs administered by the Department of Housing and Urban Development, including the Emergency Shelter Grant program (expanded from the program created by the Homeless Housing Act in 1986), the Supportive Housing Demonstration Program, Supplemental Assistance for Facilities to Assist the Homeless, and Section 8 Single Room Occupancy Moderate Rehabilitation” (National Coalition for the Homeless, 2006). The McKinney-Vento Act's four amendments have expanded its scope and strengthened its original legislation, and created new programs, such as the Shelter Plus Care Program (National Coalition for the Homeless, 2006).

The Homeless Emergency Assistance and Rapid Transition to Housing (HEARTH) Act of 2009 was signed by President Obama in 2009, and reauthorized the McKinney-Vento Homeless Assistance Act, making several changes, including a consolidation of HUD's grant programs, the creation of the Rural Housing Stability Assistance Program, and amendments to HUD's definition of homelessness and chronic homelessness (HUD, 2018). 


\section{History of HUD}

The Housing Act of 1937, also referred to as the Wagner-Steagall Act or the Low-Rent Housing Act, was created to provide subsidies to local housing agencies to assist with improving living conditions of low-income families, and was built upon the National Housing Act of 1934, which created the Federal Housing Administration. (Thompson, 2006). In 1965, HUD was created by the Department of Housing and Urban Development Act, which gave HUD status as a Cabinet- level department and its secretary the authority to direct within the department. (Thompson, 2006). A week after the assassination of Martin Luther King, Jr. in 1968, Congress passed the Civil Rights Act, also known as the Fair Housing Act, which banned most forms of housing discrimination. The Housing Act of 1968 established the Government National Mortgage Association, making mortgage funds available to moderate-income families. (Thompson, 2006).

The Housing and Community Development Act of 1974 brought three changes to policy: "halted new activity under the array of private rental housing assistance programs and reduced emphasis on Public Housing construction in favor of the new Section 8 "project-based" rental assistance program;" "introduced a fundamentally new approach to rental housing assistance- namely the "tenant-based" Section 8 program;" and "rolled seven health of cities programs into the Community Development Block Grant (CDBG) program that distributed funds annually, and largely by formula, to local governments to use with considerable discretion" (Thompson, 2006, p. 11). 
In 1990, the Cranston-Gonzalez National Affordable Housing Act (NAHA) placed emphasis on home ownership and tenant-based assistance, and launched the HOME housing block grant (Thompson, 2006). In 1998, HUD focused efforts to take action against HUD-assisted property owners and other HUD fund recipients who were violating laws and regulations with the opening of an Enforcement Center. Congress approved reforms to reduce segregation by race and income, include more working families in public housing, and increase availability of subsidized housing for impoverished families (HUD, n.d.) 


\section{LITERATURE REVIEW}

\section{Causes and Factors of Homelessness}

The National Coalition for the Homeless (NCH) (2014) lists housing and poverty as the two main causes of homelessness, "inextricably linked," but lists declining work opportunities, decreases in public assistance programs, and shortages of affordable housing, as well as other factors such as lack of affordable healthcare, domestic violence, mental illness, and addictions (National Coalition for the Homeless, 2012). While Curtis, Corman, Noonan and Reichman (2013) cite a lack of population-based data on homelessness, they also note an increasing interest in its causes and attributes. Belcher and Deforge (2012)'s study on homelessness and its causes claims that "the pathways into homelessness are complicated and may be due less to individual attributes and more to transitions, resources and events," and cite a link between capitalism and the "mal-distribution of wealth and resources to different social classes" leading to “inequality in main domains of life such as income, health, housing, nutrition, and employment" (p. 929). Their comments suggest that society is more at fault than individuals for their homelessness, because the system is designed to keep certain types of people in states of poverty and addiction no matter what efforts they make to help themselves. This theory is supported by Fargo, Munley, Byrne, Montgomery and Culhane (2013), who attribute homelessness to a "convergence of factors at multiple levels: characteristics and experiences of individuals and households, as well as conditions and forces acting in communities" (p. 340). 
Poverty forces people to choose which needs must come first when spending their limited resources each month; housing, food, childcare, healthcare, and education must be prioritized by necessity. Housing can use up a large amount of income, and individuals and families living in poverty can be one unexpected situation away from homelessness (Quigley and Raphael, 2001). When a family living in poverty is living paycheck to paycheck, an illness or accident, the primary income being taken away when a domestic abuser goes to jail, an episode of mental illness, or ongoing or new addiction can easily become the last reason that they become homeless (Thompson, 2012).

A lack of access to affordable housing and housing programs, as well as increased foreclosures, are driving forces in increased and continued homelessness. Curtis et al. (2013) found that housing markets are a major contributor to homelessness in that "housing prices exacerbate the effects of a life shock on homelessness, but there is little evidence that generosity in terms of public housing subsidies buffers the adverse effects of the shock" (p. 2246), referring to the effects that vouchers have on rent increases and housing markets. The authors also make a suggestion that "particular attention should be given to which policies work, for whom, and under what circumstances" (p. 2246-2247). Quigley and Rafael (2001) find a "powerful link between increases in inequality and increases in homelessness" within California's housing market. The authors also found that housing subsidy policies and voucher programs are effective in reducing homelessness by up to one-fourth (p. ix).

Hodge, DiPietro and Horton-Newell (2017) say of illness and homelessness, "Poor health is simultaneously a cause and consequence of homelessness. The experience 
of homelessness leads to new health conditions, exacerbates existing ones, and complicates treatment options. Consequently, homeless people have high rates of chronic disease and acute illnesses, often associated with, or exacerbated by, their living situations" (p. 28).

The idea that the closing of mental health institutions has led to an increase in homelessness and homeless individuals with mental illnesses, which are often selfmedicated with drugs and alcohol, is the focus of Quigley and Raphael's (2001) study, which reports that "the incidence of mental illness among prison and jail inmates is considerably higher than that for the non-institutional population, suggesting that the de-institutionalized [sic] mentally ill have been re-institutionalized in prisons and jails" (326). They also claim that the combination of these lead to increases in emergency room visits and jail time, and individuals are less likely to be housed in permanent housing, temporary shelters, or other forms of shelter because of un-medicated illness, addiction, and criminal records.

Discrimination continues to be a factor contributing to homelessness as society continues to view homelessness and poverty simultaneously as an acceptable reality and something to punish (Belcher and Deforge, p. 930; Hodge et al., p. 29). Belcher and Deforge (2012) write that "We ignore those individuals and groups that we find as different and/or threatening, view them as 'outsiders,' and exclude them socially" (p. 930) while offering only enough social services to sustain basic needs, but not to escape from or change their circumstances. Hodge et al. (2017) focus on how lack of affordable housing and temporary shelter increase homelessness, and how subjugation to 
"community-neutral laws" that prohibit life-sustaining activities such as sitting, lying down, eating, sleeping, camping and begging in public spaces make circumstances worse. "These enforcement measures frequently result in the destruction of homeless persons' personal property, including private documents and medications, but do not typically result in housing placements" (p. 29). Wegmann and Christensen's (2016) discussion of race, poverty and housing offers a connection between ethnicity and available housing options, as multiple cited studies (Massey and Denton, 1993, Alba and Denton, 2004, Basolo and Nguyen, 2005, Galvez, 2010) found that African American families experience constrained housing options, reduced top-choice neighborhoods, and increased housing costs. Two of these cited studies also found that among families with the same housing vouchers, African Americans and families of color lived in poorer neighborhoods than their Caucasian counterparts.

Other factors of poverty and homelessness include employment, under which fall the gap between a region's minimum and living wages, availability of employment, affordable childcare, and reliable transportation; availability of public assistance, such as welfare and social services; and overall risk, such as growing up in poverty, access to education, familial encouragement of education and gainful employment over marriage and childbearing, and the health of dependent family members, and domestic violence. 


\section{Homelessness as a Public Health Issue}

The idea of homelessness as a public health issue is multi-faceted. McKenna (2016) quotes Dr. Lee Hoffer of Case Western Reserve University, who describes the criminalization of homelessness as "bad politics," which "dehumanizes people and perpetuates both poverty and suffering [sic]," and are "detrimental to public health," and Bader (2015) states that laws that prohibit such necessary actions as sleeping and loitering outside and panhandling "[have] not helped solve the city's problem but only served as a means to disperse homeless to other locations" (p.10). McKenna's study on homeless methamphetamine users in Colorado touches on key aspects of the struggles of homelessness, such as limited access to public bathroom facilities, and lack of shelters and mental health facilities that will allow non-service dog companions. She cites a survey, Homeless Out Loud, which shows that in the city of Denver, there are thousands of homeless individuals and just 25 public bathrooms accessible to them; at night, many parks turn off drinking fountains and most public bathrooms auto-lock. Day shelters with shower services often operate on lottery systems that can take all day and interfere with other tasks. Though this limitation on access to basic hygiene

"may seem appealing to retailers and even customers, it directly curbs people's ability to survive in public spaces and negatively impacts community health... Hindering access to basic hygiene services, and even all-important hydration, drives hygiene activities into far less appropriate, unsanitary places. Forcing homeless people to wash, urinate, and defecate in the open not only violates the 
United Nations Declaration of Human Rights, but is also detrimental to community sanitation and public health" (McKenna, 2016, web).

Of mental health, McKenna (2016) focuses on drug use as a means of staying alert and awake in cities that ban public camping and sleeping in cars and other public areas. Criminal records from arrests due to unpaid tickets for public camping or sleeping or for public urination can lead to being denied access by mental health facilities, and some only provide beds for clients with permanent addresses. Drug use can create mental illnesses and add to pre-existing conditions, and limited access to medication needed to qualify for many treatment centers and shelters is exacerbated by rigid treatment schedules, ingestion instructions that require food, and the risk and trauma of belongings, such as treatment schedules and treasured personal items, being lost, confiscated, or stolen.

The stress from the constant risks of being caught and arrested or assaulted, as well as that from a lack of sleep, also lead to psychological damage. Previous trauma, from law enforcement, civilians, or other homeless individuals, can worsen encounters, leading to higher chance of injury, tickets, or arrest. In McKenna's (2016) survey of 441 homeless individuals, $36 \%$ had been arrested, $70 \%$ ticketed, and $90 \%$ harassed.

From a law enforcement perspective, homelessness is best met with coordination between police, homeless advocate organizations, and the community, according to Thompson (2015), who states that "All too often, at the point at which [sic] law enforcement gets involved, it is to take action such as arresting people or forcing movement to other areas, which is costly both in terms of the financial costs to the 
community as well as increasing distrust and conflict" (p. 1) The criminalization of homelessness comes in the form of laws that make it illegal to engage in survival tasks, such as public camping and sleeping, panhandling, and handing out food to the homeless.

Thompson's (2015) suggestion that law enforcement officers can play the part of critical partner instead of a last resort in criminalizing homelessness and making the homeless invisible is inspired by Searching out Solutions: Constructive Alternatives to Criminalization, developed by HUD, United States Interagency Council on Homelessness (USICH), the U.S. Department of Justice, and state and local partners. It involves three strategies: engage in cross-training, coordinate outreach and engagement, and form a crisis intervention team (Thompson, 2015, p. 2).

While these strategies rely on the existence of outreach and service organizations with the capacity to take in more homeless individuals and provide them with the mental health, addiction, and other specific services they need, the implementation of the strategies could lead to fewer arrests and more understanding in regard to homeless individuals and their struggles, and the providing of the necessary services to help many of them become self-sufficient and find permanent housing.

Despite an increasing standard of living in the country as a whole, homelessness continues to be a widespread issue. The Report by the National Law Center on Homelessness and Poverty (2014) cites lack of affordable housing and shelter beds, and the criminalization of homelessness in the form of anti- loitering, sleeping, begging, and sitting or lying down laws, for the increases in and perpetuating of homelessness. Such laws perpetuate public health and mental health issues by limiting safe spaces to sleep 
and rest; limit ability to feed and provide for themselves by banning panhandling and begging; limit access to better services by banning the handing out of food to homeless individuals; and decrease their chances of bringing themselves out of homelessness through the constant threat of expensive tickets and jail time, and the criminal records that they cause. As limited resources go to hotel rooms, medication, and paying off tickets, and while lack of access to regular hygiene facilities and no permanent address serve as deterrents from stable employment, homeless individuals turn to shelters that do not have the capacity to house them all, and often have strict guidelines and requirements for their clients placed on them by their funding donors.

\section{Marginalized Groups}

Homeless individuals belonging to marginalized groups experience different challenges than others. A study on elderly homeless individuals in Oakland, CA, which focused on individuals whose first instance of homelessness as an adult was at or after the age of 50, agreed with an English study that there are different risk factors and triggers of homelessness for individuals who enter homelessness at different points in their lives. Brown, Goodman, Guzman, Tieu, Ponath, and Kushel (2016) found that newly homeless older individuals usually become so due to "financial or health crisis after a lifetime of workforce participation and housing... [which] may be accentuated by a shortage of subsidized housing for older adults living in poverty, a lack of employment options for semi-skilled and unskilled laborers in late middle-age, and the inability to collect income entitlements before 65" (Brown et al., p. 2). 
Homeless veterans introduce their own set of physical and mental health and addiction issues, as the majority of them have seen active duty and many have returned with mental trauma or physical injuries. Fargo et al. (2013) list them as an at-risk population, with those from the Vietnam War at higher risk than any other group of veterans.

Members of the LGBT community find themselves especially vulnerable to homelessness and experience it at a rate disproportionate to the rest of the population; between 30 and $45 \%$ of homeless youth served by focused agencies, drop-in centers and outreach and housing programs are LGBT (Keuroghlian et al., 2014).

Homelessness in LGBT youth is caused most often by running away "from families who reject them because of sexual orientation or gender identity," being kicked out of their homes by family, or aging out of or running away from the foster care system, "where harassment and violence against LGBT youth frequently occurs" (Keuroghlian et al., p. 67). The mental health and substance abuse problems that may be associated with homelessness are increased with the homeless LGBT community, especially among youth, and rates of mental health and drug problems, suicide or suicidal acts, violence, violent victimization, and high HIV-risk behaviors are increased (Keuroghlian et al., 2014).

Individuals and families also experience homelessness differently. Fargo et al. (2013) describe rates of homelessness among families as being associated with "housing inadequacy, income, and unemployment" and being "uniquely related to factors such as religious adherence as well as public health characteristics such as births to single 
mothers, prenatal care, alcohol availability and use, and life expectancy" (p. 345). The authors compare these factors to those found among individual homeless adults, who also experience homelessness due to economic factors, but experience rates of homicide and drug use and dependence issues at higher rates. Curtis et al. (2013) discuss a study by O'Flaherty (1996) which theorized that a high-priced housing market caused landlords to stop investing in lower income rental units, forcing families to choose between poorly maintained, low quality housing and homelessness. Curtis et al. (2013) go on to compare research based on these studies that suggested that families facing disadvantages such as having young children, younger heads of households, members with substance abuse problems, paternal incarceration, infant health shocks, and with higher rental prices are at greater risk of homelessness.

\section{Other Housing Models}

\section{Housing First}

The Housing First approach to transitional housing works on the premise that homeless individuals will be more likely to succeed if given safe and stable housing before receiving supportive services. Burt (2015) makes the claim that this approach is the most effective for the chronically homeless and for those with health conditions, describing it as a program that "takes people directly from the street or shelter into housing without first requiring sobriety, medication compliance, or other things that would mean changing core behaviors before being able to access housing. The low-barrier housing first approach has proven attractive to people who cannot immediately meet demands for 
changed behavior. For them, the safety and security of housing with supports is the platform that allows them to start working on their issues" (Burt, 2015, p. 45). This approach is structured to provide coordinated medical care, mental health care, support and treatment for substance abuse, and housing. Burt (2015) emphasizes the point that there is no "one-size-fits-all" approach and that each community and geographical area will need its own structure to "take advantage of strengths and find ways to compensate for gaps and weaknesses" (60). Kresky-Wolff, Larson, O'Brien and McGraw (2010) add that this approach has been associated with decreases in use of emergency shelters, hospitalization, incarceration, and other social services costs.

Alternately, interviews with both homeless and formerly homeless individuals and shelter directors conducted by National Public Radio (NPR) (2012) provide insight on why homeless individuals often choose to be or remain homeless. These include mental illness, fear of large crowds, bed bugs and lice, personal safety such as being robbed or raped, lack of regard for quality of living, line-up times interfering with work schedules, inability to manage sobriety, rules that bar animals- certified service animals or otherwise, and PTSD conditions in veterans. Shelter directors interviewed expressed the need for better funding to offer individual or small-group locked rooms, better outreach and personal relationships, and public health preparedness. 


\section{Single Resident Occupancy Units}

Single resident occupancy (SRO) units are private rooms, often located in converted residential hotels, with shared bathrooms and kitchen facilities. They house formerly homeless individuals, "primarily low-income single adults who may be elderly or experiencing mental or physical health problems" (Shepard, 1997, p. 585-586). These units offer the freedom and privacy that does not exist in long term shelters, a sense of community that may not be found with certain types of long term or permanent housing, and offer residents counseling, case management, access to educational programs, and social activities, as well as short term funding for transportation, interview clothing, and tuition to "support efforts to obtain economic self-sufficiency" (Shepard, 1997, p. 587). These units face the danger of becoming unsafe and unsanitary when mismanaged, and one study cited by Shepard (Rollinson, 1991) found that elderly residents experienced increased isolation and lack of access to necessary social services, and many SRO units have been discontinued or demolished (p. 586).

\section{Costs of Homelessness}

In Santa Clara County, the study Home Not Found: Homeless in Silicon Valley (Flaming, Toros, and Burns, 2015), written with the County and Destination: Home, found that over a six year period between 2007 and 2012, 104,206 homeless individuals lived in the county (p. 2), at a cost of $\$ 520$ million going to health care, social services, and the justice system (p. 14). At 53\% total, health care costs consisted of 54\% outpatient care, $14 \%$ inpatient care, $27 \%$ emergency room, $17 \%$ mental health, $13 \%$ drug and alcohol 
rehab, and $6 \%$ emergency psychiatric services. Thirteen percent of the total went to social services, and $34 \%$ to the justice system (p. 2). Thirty-three percent of the individuals who received aid were involved with the criminal justice system, with 33\% charged with felonies, $50 \%$ with misdemeanors, $20 \%$ with infractions, and 33\% with drug offences (p. 8).

The county's Housing 1000 initiative was created by Destination: Home to provide supportive housing to homeless individuals (Flaming, Toros, and Burns, 2015). The county's study measured access to housing before its creation and during its start-up phase and found that before being housed, individuals cost the county an average of $\$ 62,473$ a year. After being housed, these individuals cost an average of $\$ 19,767$, with a difference of $\$ 42,706$ each (Flaming, Toros, and Burns, p. 48). It was also noted that the top $10 \%$ of individuals created $61 \%$ of all costs, averaging $\$ 67,199$ a year (Flaming, Toros, and Burns, p. 48); immigrants only accounted for $9 \%$ of the top 5\% (Flaming, Toros, and Burns, 2015 p. 16); and unlike national numbers, Santa Clara County saw equal number of male and female homeless, with females experiencing more persistent homelessness (Flaming, Toros, and Burns, 2015, p. 6), although males had a higher cost profile than females (Flaming, Toros, and Burns, 2015, p. 16).

Bader (2015) discusses the increased likelihood of homeless individuals using hospital emergency rooms (ERs) as their primary healthcare and preventative care doctors when they do not have health insurance, leading to a straining of hospital resources. Their higher risk of infectious disease, HIV, obesity, pneumonia, tuberculosis, hepatitis C, cardiovascular disease, and diabetes leads not only to increased early death 
rates, but also to increased use of ERs as primary care doctors. However, the knowledge that ERs may not refuse service can mean that homeless individuals may go to them for medication refills, medical equipment, housing resources, substance abuse treatment, or temporary shelter when inclement weather beds are not available (Flaming, Toros, and Burns, 2015, p. 9-10). Conversely, Flaming, Toros, and Burns (2015) claim that outpatient is the most frequently used service among the homeless, used by over half of homeless individuals, while emergency room services are used by just over $25 \%$ (12). The authors associate the highest costs of homelessness with those experiencing "persistent homelessness," but claim that the prioritization of housing for this population would offset the costs of services provided (p. 1).

\section{Barriers to Success}

Bader's (2015) study on the Housing 100 Care Coordination Project references several barriers met in case management assistance to assisting homeless individuals and families in finding permanent housing. These barriers include "financial support, substance abuse and treatment programs, medical and mental health complications, elderly and frail, and problems in the legal system. What makes these barriers difficult to address is the interrelatedness of them to each other" (p. 13).

Financial assistance is one of the biggest barriers, covering ineligibility for Social Security Disability Insurance (SSDI), being on SSDI and unable to return to work, or inability to return to work due to substance or alcohol dependency, age, or mental health (p. 13). 
Substance abuse treatment dependent on the following factors: " 1 . Whether or not the individual is motivated to change, 2 . Whether there are any appropriate programs for the individual to participate in, and 3. Whether the individual been barred from any program due to past behaviors. Oftentimes, lack of motivation or unwillingness to change the behavior is a leading factor in failing to find housing” (p. 13).

Other factors that interfere with case management assistance include automobile related, decline in public assistance, divorce, domestic violence, illness, job loss, lack of affordable housing, lack of child support, low wages, natural disaster, post traumatic stress disorder (PTSD), severe depression, and tragedy (p. 14).

\section{Alcohol and Substance Abuse}

Bader describes substance abuse as being one of the most common disabling conditions found within Santa Clara County's homeless population, experiences by $39 \%$ of individuals, second only to mental health (46\%) (p.2). Alcohol and substance abuse were found to contribute to "co-occuring mental health disorders" (p. 10), and are associated with and contribute to both mental health and law enforcement issues (p. 11). These three factors "may overlap and be so intertwined that an individual cannot be placed in permanent housing unless all three are addressed at the cost of considerable time and resources" (p. 11).

Bader also found that " $40 \%$ of homeless individuals suffer from alcohol related disorders, $25 \%$ from drugs, $13 \%$ from psychosis, $11 \%$ from depression, $23 \%$ from 
personality disorder, and 73\% from an unmet medical need;" and that alcohol and substance dependence are closely associated with housing placement and employment ( $\mathrm{p}$. $11)$.

\section{Comparison of Emergency, Transitional and Permanent Program Costs}

Ly and Latimer (2015)'s study of the cost benefits of the Housing First model found that while only comprising $20 \%$ of shelter users, the chronically homeless consume the largest portion of health, social, and justice services. Their study on the costs of programs which had adopted the Housing First model versus programs which had not, found decreases in costs related to inpatient care, which the authors note may be attributed to increased outpatient and regular care; and "justice costs." The decreases in jail, court, and legal costs are attributed to a decrease in arrests for petty crimes associated with survival, such as entering private property or sleeping in public places. The authors also made an association between severe psychiatric symptoms and nonviolent crimes, the rate of which decreased with stable housing; "by providing housing to homeless people and support to stabilize mental health symptoms, a decrease in police contacts, arrests, detentions, and court appearances can be expected" (Ly and Latimer, 2015, p. 482).

The increase in costs was found to be from social services. With permanent addresses and additional support, individuals, especially those with mental or physical disabilities, were more likely to be signed up for various income and insurance assistance programs (Ly and Latimer, 2015, p. 482). 


\section{METHODOLOGY}

This research was based on an outcomes evaluation approach for the County of Santa Clara's THU programs as they meet the goals of Destination: Home's Community Plan to End Homelessness 2015-2020 and Santa Clara County's Point-in-Time survey counts.

This outcome evaluation was used to conclude whether the THU program has been successful. Its elements consisted of a measure of its outcomes, whether the program accomplished what it promised, and an impact analysis of whether the program affected its target populations as intended. The data used in this process was used to measure the effectiveness of the THU program by comparing the Community Plan's shelter goals for its three target populations to the data provided by Santa Clara County and the agency LifeMoves. Comparison of these data was used to measure the success of the THU program. A logic model following the outcomes evaluation model was used to present the inputs, processes, outputs and outcomes of the THU program, and indicators created for each output to present a comparison of the data used to measure the program's success. Additionally, a participant-observer approach was also taken to provide both context and the writer's personal experience working with homeless populations in the city of San Jose. Descriptions of this additional approach and experiences to offset to the data are located at the end of the Findings and Analysis sections of this paper.

Data from the target populations were compared from 2007, 2009, and 2011 as data was available through 2017 for total populations and sheltered populations. A community example, the agency LifeMoves's data, on total number of annual THU clients, sheltered target populations, age range, and program recurrence (recidivism) and 
rehousing rates within its THU programs were used for comparison. Comparison of these data with the Community Plan's goals determined whether they were being met.

Fulfillment of these goals were measured by:

- 2013 Point-in-Time survey target populations being sheltered

○ Compare to 2015 and 2017 numbers

- Community example: Santa Clara County THU agency, LifeMoves target

populations data, homelessness recurrence (or recidivism) rates

- Are the Community Plan's three goals (Tables 3-5) being met?

\section{Logic Model}

\begin{tabular}{|l|l|}
\hline \multicolumn{1}{|c|}{ Outcomes } & Indicators \\
\hline $\begin{array}{l}\text { Individuals and families given shelter while } \\
\text { accessing resources for long-term } \\
\text { independence }\end{array}$ & $\%$ of target populations sheltered \\
\hline Individuals and families permanently housed & $\%$ permanently housed \\
& $\%$ returning to homelessness \\
\hline
\end{tabular}

\section{Data Collection}

County population data were collected from the 2013, 2015, and 2017 Santa Clara

Point-in-Time surveys and the county’s Community Plan to End Homelessness

2015-2020.

LifeMoves and HUD data were collected from the HMIS Clarity database website using employee login and the website's Reports function. The data on annual numbers and age range were collected through the Program Based Reports function by choosing 
THU programs, Santa Clara County, “all” veteran options (veteran and non-veteran), and choosing the dates January 1 through December 31 for the years 2013, 2014, 2015, 2016, and 2017. Program Recidivism data was found through the Program Based Reports function by choosing “Transitional Housing," "All Programs," and the dates January 1 through December 31 for the years 2013 through 2017. The HUD Reports function was used to collect the target population data. THU Individuals or THU Families, Santa Clara County, "all" veteran options, and the dates January 1 through December 31 for the years 2013, 2014, 2015, 2016, and 2017. 


\section{FINDINGS}

Community Plan Target Populations in 2013 through 2017: Table A-Sheltered individuals and families, Numbers and Percentages

\begin{tabular}{|c|c|c|c|c|c|}
\hline Target Population & $\begin{array}{l}2013 \text { Goals } \\
\text { (Sheltered) }\end{array}$ & 2015 (number) & $\begin{array}{l}2015 \\
\text { (percentage) }\end{array}$ & $\begin{array}{l}2017 \\
\text { (number) }\end{array}$ & $\begin{array}{l}2017 \\
\text { (percentage) }\end{array}$ \\
\hline $\begin{array}{l}\text { Chronically } \\
\text { Homeless }\end{array}$ & 2,518 & $\begin{array}{l}2,169 \text { individuals, } \\
13 \text { families ( } 38 \text { family } \\
\text { members) }\end{array}$ & $8 \%, 13 \%$ & $\begin{array}{l}2,097 \\
\text { individuals }\end{array}$ & $14 \%$ \\
\hline Veterans & 718 & $\begin{array}{l}683 \text { individuals, } \\
20 \text { families ( } 20 \\
\text { veterans, } 24 \\
\text { non-veterans) }\end{array}$ & $37 \%, 15 \%$ & 660 individuals & $32 \%$ \\
\hline $\begin{array}{l}\text { Children, Youth, } \\
\text { Families }\end{array}$ & 2,333 & $\begin{array}{l}908 \text { individuals (266 } \\
\text { households) }\end{array}$ & $94 \%$ & $\begin{array}{l}294 \text { families, } \\
1,075 \\
\text { individuals }\end{array}$ & $72 \%$ \\
\hline $\begin{array}{l}\text { Unaccompanied } \\
\text { children, } \\
\text { transition-age-yo } \\
\text { uth, parenting } \\
\text { youth }\end{array}$ & $\mathrm{n} / \mathrm{a}$ & $\begin{array}{l}59 \text { unaccompanied } \\
\text { children, } \\
824 \\
\text { transition-age-youth, } \\
40 \text { parenting } \\
\text { transition-age youth }\end{array}$ & $\begin{array}{l}31 \%, 10 \%, \\
85 \%\end{array}$ & $\begin{array}{l}509 \text { un- } \\
\text { accompanied } \\
\text { children: } \\
2,021 \\
\text { transition-age- } \\
\text { youth }\end{array}$ & $\begin{array}{l}\text { (total) } \\
4 \%\end{array}$ \\
\hline
\end{tabular}

County of Santa Clara (2015); County of Santa Clara (2017). 
Community Plan Target Populations in 2013 through 2017: Table B

\begin{tabular}{|l|l|l|l|l|l|}
\hline Target Population & $\begin{array}{l}2013 \text { Goals } \\
\text { (Sheltered) }\end{array}$ & $\begin{array}{l}2015 \\
\text { Individuals } \\
\text { (total) }\end{array}$ & $\begin{array}{l}\text { 2015 Individuals } \\
\text { (sheltered) }\end{array}$ & $\begin{array}{l}\text { 2017 Individuals } \\
\text { (total) }\end{array}$ & $\begin{array}{l}\text { 2017 Individuals } \\
\text { (sheltered) }\end{array}$ \\
\hline Chronically Homeless & 2,518 & 2,169 & 201 & 2,097 & 293 \\
\hline Veterans & 718 & 683 & 253 & 660 & 211 \\
\hline $\begin{array}{l}\text { Children, Youth, } \\
\text { Families }\end{array}$ & 2,333 & 908 & 853 & 1,075 & 774 \\
\hline $\begin{array}{l}\text { Unaccompanied } \\
\text { children, } \\
\text { transition-age-youth, } \\
\text { parenting youth }\end{array}$ & 0 & 923 & 134 & 2,530 & 101 \\
\hline
\end{tabular}

County of Santa Clara (2015); County of Santa Clara (2017).

Figure A: Community Plan Target Populations in 2013 through 2017

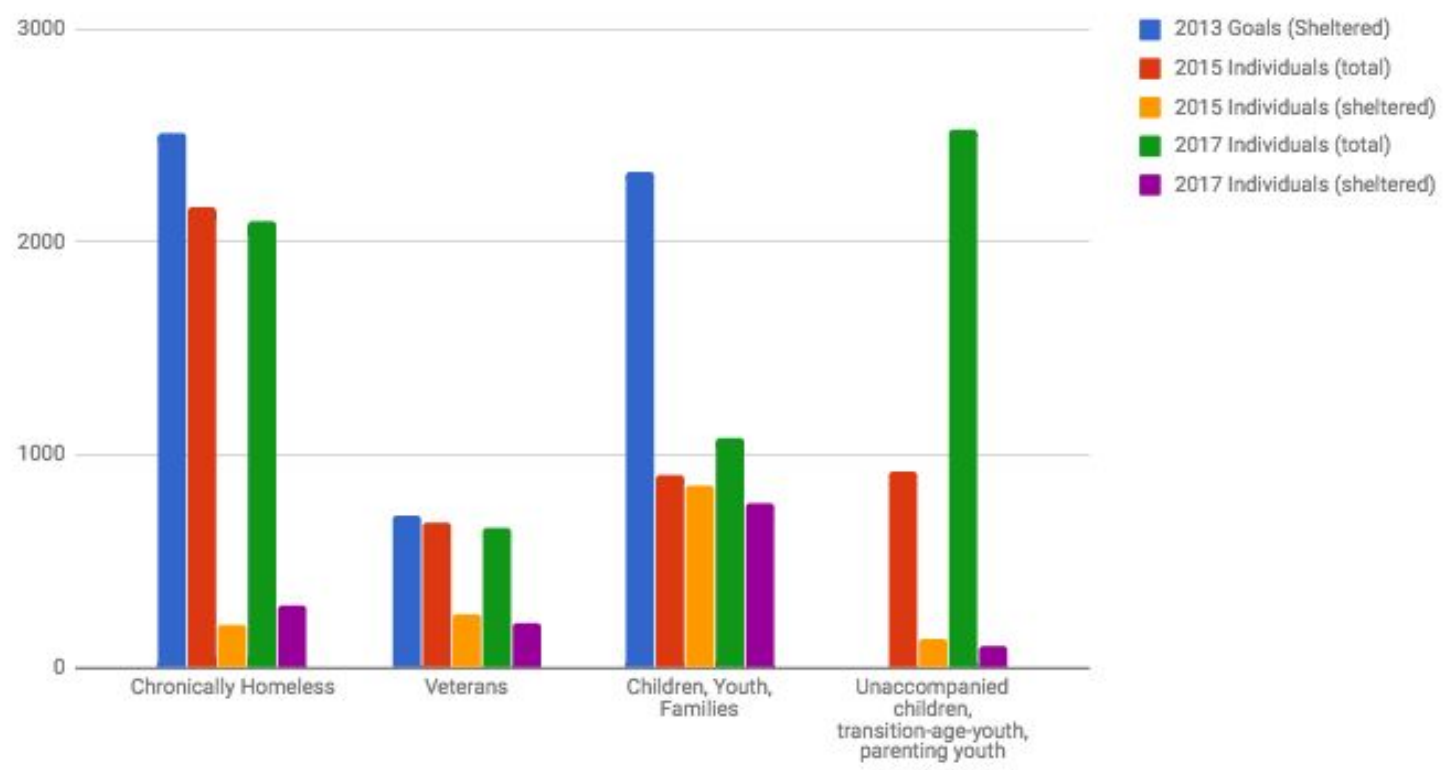

Source: County of Santa Clara (2015); County of Santa Clara (2017). 
Community Plan Target Populations in 2013 through 2017 Table A was included to provide original data and percentages for transparency of the math used to create Table B. In Table B, "2017 Individuals (total)" is a combination of "Unaccompanied children, transition-age-youth, parenting youth” from Table A. Table B's “2015 Individuals (sheltered)" and "2017 Individuals (sheltered)" were determined by multiplying the total number by the percentage of sheltered from Table A. The subsections of "unaccompanied children" and "transition-age-youth" refer to youth under the age of 18 with no parent or guardian and between 18 and 24 years old, respectively.

\section{Data Limitations}

The county's 2017 methodology includes disclaimers that their "blitz count and survey," conducted by a large number of people over a short amount of time to avoid enumeration and in an effort to respect confidentiality, leaves out certain identifiable information, possibly leading to values omitted from results which may cause the number of respondents for some questions to not always match the total number of conducted surveys. The survey was conducted with "randomized survey sampling process, these 587 valid surveys represent a confidence interval of $+/-4 \%$ with a $95 \%$ confidence level when generalizing the results of the survey to the estimated population of homeless individuals in Santa Clara County" (Santa Clara County Point-in-Time, 2017, p. 15).

The county's 2015 survey includes "transition-age-parenting-youth," defined as "youth identifying as parent or legal guardian of one or more children who are present in the same place as that youth parent, where there is no person over the age of 24 in the 
household" (Santa Clara County Point-in-Time Survey 2015, p. 55). The 2017 survey describes the fluctuation in families, with a decrease from 2013 and an increase from 2015, as being caused by "increased inclusion of data from McKinney-Vento representatives from the many participating school districts" and "the largest increase in participation in the history of the Census from local school representatives, thanks to the County Office of Education (COE)... (W)hile not all districts participated, far more participated than in past years, providing increased access to a frequently overlooked population" (Santa Clara County Point-in-Time, 2017, p.44). Data is admittedly lacking for the target population of homeless youth, "due to the often hidden nature of youth homelessness," but in an effort to improve data, an expanded and more dedicated youth-focused census and survey has been implemented in 2015 and 2017, leading to an increase in the number of both participating program staff and coverage of areas frequented by homeless youth; this is a contributing factor in the increase in homeless youth counted (p. 49). The Point-in-Time analysis notes that while "significant investments and reforms" have been made to meet the needs of homeless individuals, the 2017 survey indicates an increased number of such individuals when compared to 2015, and attributes this increase to reasons such as "macroeconomic concerns and difficulties finding locations to live" (p. 55).

It is also noted that homeless families are underrepresented in the survey, due to sample execution issues; the Point-in-Time analysis states that "in 2017, shelter staff reported difficulties completing surveys of families, due to a variety of reasons" (Santa Clara County Point-in-Time, 2017, p. 46), but does not list those reasons, and cautions 
against interpretation of the data due to the small number of individuals within families surveyed. Because the county's survey uses HUD's definition of homelessness, which does not include individuals and families living with friends or relatives ("couch surfing" or living in hotels or motels) or about to lose their permanent housing, an accurate count of homeless families may not be entirely possible (p. 9).

\section{Community Example: LifeMoves THU Program's Target Populations}

Table 6: Number of Clients, LiveMoves THU Programs

\begin{tabular}{|l|l|l|l|l|l|}
\hline Year & 2013 & 2014 & 2015 & 2016 & 2017 \\
\hline Number & 237 & 289 & 375 & 449 & 528 \\
\hline$\%$ Increase & $\mathrm{n} / \mathrm{a}$ & $22 \%$ & $29.8 \%$ & $16.5 \%$ & $17.6 \%$ \\
\hline
\end{tabular}

Source: Homeless Management Information System (2018).

Table 7: Age Range, LiveMoves THU Programs

\begin{tabular}{|l|r|r|r|r|r|}
\hline & 2013 & 2014 & 2015 & 2016 & 2017 \\
\hline Under 5 & 10 & 24 & 48 & 50 & 62 \\
\hline $5-12$ & 15 & 14 & 20 & 41 & 61 \\
\hline $13-17$ & 6 & 9 & 9 & 10 & 16 \\
\hline $18-24$ & 5 & 19 & 20 & 12 & 37 \\
\hline $25-43$ & 44 & 47 & 73 & 74 & 92 \\
\hline $35-44$ & 44 & 57 & 56 & 81 & 96 \\
\hline $45-54$ & 61 & 68 & 72 & 85 & 96 \\
\hline $55-61$ & 38 & 40 & 54 & 71 & 48 \\
\hline $62+$ & 10 & 7 & 21 & 25 & 20 \\
\hline No answer & 4 & 4 & 2 & 0 & 0 \\
\hline Total & 237 & 289 & 375 & 449 & 528 \\
\hline
\end{tabular}

Source: Homeless Management Information System (2018). 
Table 8: Community Plan Target Populations, LiveMoves THU Programs

\begin{tabular}{|l|l|l|l|l|l|}
\hline & 2013 & 2014 & 2015 & 2016 & 2017 \\
\hline $\begin{array}{l}\text { Chronically } \\
\text { Homeless }\end{array}$ & 1 & 8 & 43 & 70 & 96 \\
\hline $\begin{array}{l}\text { Veteran } \\
\text { (individuals) }\end{array}$ & 31 & 49 & 75 & 83 & 42 \\
\hline $\begin{array}{l}\text { Family with } \\
\text { Children }\end{array}$ & 48 & 90 & 148 & 161 & 236 \\
\hline $\begin{array}{l}\text { Unaccompanied } \\
\text { children } \\
\text { ("children-only" } \\
\text { households) }\end{array}$ & 0 & 0 & 3 & 6 & 1 \\
\hline $\begin{array}{l}\text { Transition-age- } \\
\text { youth }\end{array}$ & 3 & 9 & 9 & 7 & 21 \\
\hline
\end{tabular}

Source: Homeless Management Information System (2018).

\section{Community Example: LifeMoves THU Programs "Recidivism" and Rehousing Rates}

For the purpose of this research, the term "recurrence" has been used to describe individuals who returned to homelessness after staying at a shelter. HMIS Clarity's use of the term "recidivism" is in this case synonymous with "return to homelessness" and is used in Tables 9 and 10 as a synonym for "recurrence."

In Table 9, "number of clients who exited within date range" refers to all program participants from January 1 to December 31 of each sample year. "Number of clients who exited to permanent destinations" refers to program participants who left the program to housing. "Number of clients returning to homelessness" refers to program participants who left the program, either from timing out or being discharged for noncompliance, without permanent housing. "Average number of days from program exit 
to re-entry" refers to the average time program participants take from discharge, either to permanent housing or to return to homelessness, to re-enter the THU program. Note that HMIS Clarity does not include in "Program Recidivism" data on number of former program participants returning to the THU program each year and roughly $50 \%$ of program participants were counted in this report; "Percentage not accounted for" was calculated and added to account for these missing data.

Table 9: Program Exit and Recurrence/Recidivism in LiveMoves THU Programs

\begin{tabular}{|l|c|c|c|c|c|}
\hline & 2013 & 2014 & 2015 & 2016 & 2017 \\
\hline $\begin{array}{l}\text { Number of } \\
\text { clients who } \\
\text { exited within } \\
\text { date range }\end{array}$ & 181 & 190 & 252 & 302 & 410 \\
\hline $\begin{array}{l}\text { Number of } \\
\text { clients who } \\
\text { exited to } \\
\text { permanent } \\
\text { destinations } \\
\text { (rehoused) }\end{array}$ & 91 & 104 & 132 & 176 & 232 \\
\hline $\begin{array}{l}\text { Number of } \\
\text { clients returning } \\
\text { to homelessness }\end{array}$ & 31 & 29 & 36 & 51 & 31 \\
\hline $\begin{array}{l}\text { Average number } \\
\text { of days from } \\
\text { program exit to } \\
\text { re-entry }\end{array}$ & 498 & 346 & 214 & 247 & 92 \\
\hline
\end{tabular}

Source: Homeless Management Information System (2018). 
Table 10: Transition to Permanent Housing and Homeless Recurrence (Recidivism) by Percentage LiveMoves THU Programs

\begin{tabular}{|l|l|l|l|l|l|}
\hline & 2013 & 2014 & 2015 & 2016 & 2017 \\
\hline $\begin{array}{l}\text { Number of } \\
\text { clients who } \\
\text { exited to } \\
\text { permanent } \\
\text { destinations } \\
\text { (rehoused) }\end{array}$ & $38.4 \%$ & $36.0 \%$ & $35.2 \%$ & $39.2 \%$ & $43.9 \%$ \\
\hline $\begin{array}{l}\text { Number of } \\
\text { clients } \\
\text { returning to } \\
\text { homelessness }\end{array}$ & $13.1 \%$ & $10.0 \%$ & $9.6 \%$ & $11.4 \%$ & $5.9 \%$ \\
\hline $\begin{array}{l}\text { Percentage not } \\
\text { accounted for }\end{array}$ & $51.5 \%$ & $46.0 \%$ & $44.8 \%$ & $50.6 \%$ & $49.8 \%$ \\
\hline
\end{tabular}

Source: Homeless Management Information System (2018).

\section{Participant-Observer Approach}

Per Kawulich (2005)'s definition of the Participant Observation data collection approach, "the process enabling researchers to learn about the activities of the people under study in the natural setting through observing and participating in those activities" and "the process of learning through exposure to or involvement in the day-to-day or routine activities of participants in the researcher setting" (web), the writer used this approach in addition to the outcomes approach to include employment observation data to the analysis of the measured success of the Community Plan and the THU program. 
The writer works with the single men's population of the LifeMoves San Jose Montgomery Street Inn (MSI) location. Findings include the population consisting of all three definitions of homeless individuals: episodic homeless individuals, in the Emergency Shelter (ES) program, the majority of whom are in their 20s or 30s, have often recently become homeless and use the agency's services to find employment and general assistance, and find permanent housing within the time limits of their program, or after an extension. Some leave before their program time ends or have their program terminated due to substance or alcohol use. 


\section{ANALYSIS}

\section{Community Plan Target Populations}

Data provided by Santa Clara County's Point-in-Time surveys did not provide the same level of detail for each target population for each year. In 2013, the survey offers the number of individuals, while in 2015 and 2017, the number of individuals is accompanied by the number of families and the percentages of those sheltered; in 2015, the survey includes the population "parenting transition-age-youth," and in 2013 provides no data at all for unaccompanied children, transition-age-youth, or parenting youth. While this population is not expressly included in the County's target populations, it may be included with the families with children population, as it contains both children and youth-as-head-of-household families.

Comparison of 2015 and 2017's data (Table A) of sheltered target populations to 2013's goals show a marked failure to meet said goals. Chronically homeless individuals show the lowest rates of being sheltered, experiencing a 1\% (92 individuals) increase from 2015 to 2017 . Veterans saw a decrease in homeless individuals from 683 in 2015 to 660 in 2017 (23 individuals). Of those counted, the number of sheltered veterans decreased from $37 \%$ to $32 \%$. An increase was counted in both the number of homeless families and individuals within families, but a decrease of $22 \%$ in sheltered families. The data for unaccompanied youth was incomparable as presented in the 2015 and 2017 counts, but when consolidated in Table B, the data showed an increase in individuals counted and a decrease in individuals sheltered. 


\section{Community Example: LifeMoves THU Programs}

LifeMoves THU program participants steadily increased over the provided year range of 2013 to 2017 in numbers, but increase by percentage fluctuates, with a large decrease (13.3\%) in 2015 and an increase of only $1.1 \%$ in 2017. In the demographic of age (Table 7), each program participant is counted. An increase in every age group is seen each year, with the exception of ages 55-61, which steadily increased to 71 until 2015 but decreased to 48 in 2017 and ages 62+, which similarly increased to 25 in 2015 and decreased to 20 in 2017.

Demonstrated in Table 8, an overall increase was also seen in the number of program participants belonging to the Community Plan's target populations. Chronically homeless individuals, families with children, and transition-age-youth steadily increased from 2013 to 2017; veterans increased until 2016 and then decreased by half in 2017 (from 83 to 42); and unaccompanied children, or "children-only households," were not counted until 2015 and saw fluctuations from 3 to 6 to 1 individuals in 2015, 2016 and 2017. Overall, an increase in intakes of individuals from target populations trended over the course of the sample years.

Program exit data (Table 9) exhibited an increasing trend of program participants who exited the program within the date range- an increase in clients leaving each year, proportionate to the increase in THU program clients each year. Program participants who exited to permanent housing increased every year, while those exiting the program to return to homelessness fluctuated, ending on a low point in 2017. The average number of days between program exit and re-entry decreased significantly, with former program 
participants having less time between program exit and recurrence. Program participants' success and return to homelessness were measured in Table 5 by calculating the percentages of each data set from each sample year's total number of program participants. The percentage of participants who exit the THU program for permanent housing increased steadily, seeing only a decrease from 2013 to 2014 . The percentage of participants returning to homelessness after exiting the program steadily decreased, with one increase in 2016 before a decrease of more than half in 2017. These data sets make up roughly half of each sample year's program participants; the other $50-54 \%$ are unaccounted for and not included in HMIS Clarity's Program Exit and Recurrence (Recidivism) reports, but could account for participants still enrolled in the program.

\section{Participant-Observer Analysis}

The Drug and Alcohol Department Services (DADS) and Substance Use Treatment Services (SUTS) programs bring clients recently released from jail and with both the clients and their probation or parole officers to meet the conditions of their probation or parole. These clients often have families they plan to live with once their program ends and in the writer's experience are the more successful group of clients.

Chronically homeless clients include clients from both the ES and veterans' programs, Veteran Medical Respite (VMR) and Grants Per Diem (GPD). These individuals are often referred by off-site case managers, social workers, or Veterans' Affairs (VA), and many are repeat clients, staying for the duration of their program or having their program terminated; return to homelessness or go to another shelter; and 
return to MSI after the 90 day waiting period or after being referred again by the VA hospital.

Because MSI's capacity comprises such a small portion of the Community Plan's target population goals, with just 85 beds, less than 20 of which are reserved for veterans, and is a site for single men, not families, this site's contribution to meeting these goals is only measurable in part. Implementation of elements of the Housing First theory has increased the success of clients, as while they are required to pass drug and alcohol tests upon intake (with the exception of VMR clients), clients who relapse are not immediately terminated from their program, but instead offered additional support, case management and treatment options. The writer has seen this implementation decrease the number of clients who leave the site prematurely, return to substance abuse, and exhibit behaviors that may ban them from agency services in the future.

The writer has also observed that recurring clients, in equal measure leave the first time due to program termination and successful housing. In both instances clients are more likely to succeed after returning to MSI, with the exception of chronically homeless clients, who usually return to homelessness after either completing their program (receiving no extensions after their 90 day program ends) or having their program terminated due to various behaviors. 


\section{Outcomes Evaluation Analysis}

\begin{tabular}{|l|l|l|l|}
\hline Measure & Indicator (2017) & $\begin{array}{l}\text { Community Plan } \\
\text { Goal }\end{array}$ & Impact analysis \\
\hline $\begin{array}{l}\text { Individuals and } \\
\text { families given shelter } \\
\text { while accessing } \\
\text { resources for } \\
\text { long-term } \\
\text { independence }\end{array}$ & $\begin{array}{l}\text { 293 of 2,097 }(14 \%) \\
\text { Chronically homeless } \\
\text { sheltered }\end{array}$ & $\begin{array}{l}\text { 2,518 Chronically } \\
\text { homeless sheltered }\end{array}$ & $\begin{array}{l}\text { Increase in } \\
\text { chronically homeless } \\
\text { individuals, goal not } \\
\text { being met }\end{array}$ \\
\hline & $\begin{array}{l}211 \text { of } 660(32 \%) \\
\text { veterans sheltered }\end{array}$ & $\begin{array}{l}718 \text { veterans } \\
\text { sheltered }\end{array}$ & $\begin{array}{l}\text { Increase in homeless } \\
\text { veterans, goal not } \\
\text { being met }\end{array}$ \\
\hline $\begin{array}{l}\text { Individuals and } \\
\text { families permanently } 1,075(72 \%) \\
\text { housed }\end{array}$ & $\begin{array}{l}\text { families with children } \\
\text { sheltered }\end{array}$ & $\begin{array}{l}\text { 2,333 families with } \\
\text { children sheltered }\end{array}$ & $\begin{array}{l}\text { Increase in homeless } \\
\text { families, goal not } \\
\text { being met }\end{array}$ \\
\hline $\begin{array}{l}\text { permanently housed } \\
\text { to homelessness }\end{array}$ & $\begin{array}{l}\text { Actions 1 and 2: } \\
\text { hanaging and ending } \\
\text { the Housing First } \\
\text { plan; providing } \\
\text { different housing } \\
\text { types to meet } \\
\text { population needs }\end{array}$ & $\begin{array}{l}\text { Overall increase in } \\
\text { permanently housed } \\
\text { individuals and } \\
\text { families }\end{array}$ \\
\hline $\begin{array}{l}\text { Action 3: Preventing } \\
\text { obstacles to } \\
\text { permanent housing } \\
\text { by addressing unique } \\
\text { challenges }\end{array}$ & $\begin{array}{l}\text { Overall decrease in } \\
\text { return to } \\
\text { homelessness }\end{array}$ \\
\hline
\end{tabular}

Overall, the Community Plan's goals are not being met. The most current count from 2017 shows that not only have the target populations' numbers increased since the Plan was introduced in 2013, but that chronically homeless, homeless veterans, and homeless families with children are being sheltered at $14 \%, 32 \%$, and $72 \%$, respectively. 
The Plan does not give a percentage at which its programs may be considered successful, for the sake of analysis, the current percentages of chronically homeless and homeless veterans could by no measure be considered successful.

The Plan's three Actions of managing and ending homelessness through the Housing First plan, providing different housing types to meet population needs, and preventing and addressing obstacles to permanent housing by addressing unique challenges, can be measured through the community example agency LifeMoves' data of permanently housed and returning to homelessness data. Consistent increases in the percentage of individuals and families being permanently housed and decreases in individuals and families returning to homelessness may be considered successful. 


\section{CONCLUSION}

Given that the cost of housing homeless individuals has been shown to cost an average of $\$ 42,700$ less per year than continued homelessness (Flaming, Toros, and Burns, p. 48), each THU program may be considered a success to the county. The community example of the agency LifeMoves' data of annual increases in permanently housed program participants and annual decreases in returns to homelessness show specific program success increasing each year in proportion to increasing numbers of program participants.

\section{Recommendation}

While the community example agency LifeMoves demonstrates both an increase in individuals and families reached and permanently housed, the most recent Point-in-Time surveys show a disproportionate number of the Plan's target populations are not being sheltered. Santa Clara County's 2015 survey observes that "the need for housing and services remains high... Taking into account vacancies in existing facilities and projects under development, over 4,000 temporary and permanent housing units are needed just to meet the immediate need to move unsheltered individuals and families off the streets" (2015, p. 59-60), emphasizing the fact that the Plan's goals need not only to call for sheltering and eventual housing of all homeless individuals and families, but that the THU program requires more community and county funding and outreach if it is to have an impact on the county's homeless population. LifeMoves' rates of permanent housing 
may be increasing steadily, but its return to homelessness rates speak to persistent barriers to permanent housing. 


\section{SOURCES CONSULTED}

Alba, R., \& Denton, N. A. (2004). Old and new landscapes of diversity: The residential patterns of immigrant minorities. In I. Foner \& G. M. Fredrickson (Eds.), Not just Black and White, New York, NY: Russell Sage Foundation, 237-261.

Bader, D. K. (2015). An Outcome Analysis of the Achievement of the Five Objectives by the Housing 1000 Care Coordination Project: Ending Homelessness in Santa Clara County Through Affordable Housing. Master's Projects. SJSU Scholarworks. Retrieved from www.scholarworks.sjsu.edu/cgi/viewcontent.cgi?article $=1423 \&$ context $=$ etd_projects

Basolo, V., \& Nguyen, M. T. (2005). Does mobility matter? The neighborhood conditions of housing voucher holders by race and ethnicity. Housing Policy Debate, 16(3-4), 297-324.

Belcher, J.R. \& Deforge, B.R. (2012). Social Stigma and Homelessness: The Limits of Social Change. Journal of Human Behavior in the Social Environment, 22(8), 929-946.

Bill Wilson Center. (no date). All Services. Retrieved from www.billwilsoncenter.org/services/?PHPSESSID=5ee11b1 f8dfc53a3e2e74c6e1a91aefb

Brown, R.T., Goodman, L., Guzman, D., Tieu, L., Ponath, C., Kushel, M.B. (2016). Pathways to Homelessness among Older Homeless Adults: Results from the HOPE HOME Study. Plos ONE, 11(5), 1-17.

Bloomberg, S. (2017). A Legacy of Criminalizing Transience and Homelessness. San Francisco Public Press.

www.sfpublicpress.org/news/homelessness/navigation/2017-06/a-legacy-of-criminalizing -transience-and-homelessness

Burt, M.R. (2015). Serving People with Complex Health Needs: Emerging Models, With a Focus on People Experiencing Homelessness or Living in Permanent Supportive Housing. American Journal of Psychiatric Rehabilitation, 18(1), 42-64. 
California Code of Regulations. (2017). § 3378.7. Transitional Housing Unit. Retrieved from

www.govt.westlaw.com/calregs/Document/I81BF86005CEB11E4A75DD2EED456709D ?viewType $=$ FullText\&originationContext $=$ documenttoc\&transitionType $=$ CategoryPageIt em\&contextData $=(\mathrm{sc}$. Default $)$

City of San Jose. (2017). 2017 Homeless Census and Survey Comprehensive Report. www.sanjoseca.gov/DocumentCenter/View/70076

County of Santa Clara. (2015). Homeless Point-in-Time Census and Survey Comprehensive Report 2015. Retrieved from www.sccgov.org/sites/oah/coc/census/Documents/SantaClaraCounty_HomelessReport_2 015_FINAL.pdf

County of Santa Clara. (2017). Homeless Point-in-Time Census and Survey Comprehensive Report 2017. Retrieved from www.sccgov.org/sites/osh/ContinuumofCare/ReportsandPublications/Documents/2017\% 20Santa\%20Clara\%20County\%20Homeless\%20Census\%20and\%20Survey\%20Report.p df

Curtis, M.A., Corman, H., Noonan, K., \& Reichman, N.E. (2013). Life Shocks and Homelessness. Demography, 50(6), 22277-2253.

Destination: Home. (2014). Community Plan to End Homelessness in Santa Clara County. Retrieved from www.destinationhomescc.org/wp-content/uploads/2015/02/Community_Plan_to_End_H omelessness_in_Santa_Clara_County_web.pdf

Destination: Home. (2016). Community Plan to End Homelessness in Santa Clara County. Retrieved from www.destinationhomescc.org/wp-content/uploads/2016/06/Community-Plan-to-End-Ho melessness-2016-Annual-Report.pdf

Destination: Home. (2018). Our Work. The 2015-2010 Community Plan to End Homelessness. Retrieved from www.destinationhomesv.org/our-work/ 
Dickey, M.R. (2018). Cisco commits to $\$ 50$ million to end homelessness in Silicon Valley. Tech Crunch. Retrieved from

www.techcrunch.com/2018/03/26/cisco-commits-50-million-to-address-homelessness-insilicon-valley/

Fargo, J.D., Munley, E.A., Byrne, T.H., Montgomery, A.E., \& Culhane, D.P. (2013). Community-Level Characteristics Associated with Variation in Rates of Homelessness Among Families and Single Adults. American Journal of Public Health, 103(S2), S340-S347.

Flaming, D.J., Toros, H. and Burns, P. (2015). Home Not Found: The Cost of Homelessness in Silicon Valley. Economic Roundtable Research Report, 2015. Retrieved from www.economicrt.org/publication/home-not-found/

The Health Trust. (2017). Homelessness \& Food Security in Silicon Valley. Retrieved from

www.healthtrust.org/wp-content/uploads/2017/05/2017-05-Spring-Summer-Magazine-O nline-PDF-1.pdf

Galvez, M. M. (2010, August). What do we know about housing choice voucher program location outcomes? A review of recent literature. Washington, DC: What Works Collaborative, Urban Institute. Retrieved from www.urban.org/what-works-collaborative.cfm

Henwood, B.F., Cabassa, L.J., Craig, C.M., Padgett, D.K. (2013). Permanent Supportive Housing: Addressing Homelessness and Health Disparities? American Journal of Health, 103(S2), S188-S192.

Hodge Jr., J.G., DiPietro, B., \& Horton-Newell, A.E. (2017). Homelessness and the Public's Health: Legal Responses. Journal of Law, Medicine \& Ethics, (45), 28-32.

Home First. (no date). Programs. Retrieved from www.homefirstscc.org/our-programs/

Homeless Management Information System. (2018). Demographics, THU Program, 2013-2017. [Data report]. Location: HMIS Clarity. 
Homeless Management Information System. (2018). HUD Reports, THU Program, 2013-2017. [Data report]. Location: HMIS Clarity.

Homeless Management Information System. (2018). Program Recidivism, THU Program, 2013-2017. [Data report]. Location: HMIS Clarity.

HUD. (2013). Expanding Opportunities to House Individuals and Families Experiencing Homelessness through the Public Housing (PH) and Housing Choice Voucher (HCV) Programs: Questions and Answers (Q\&As) September, 2013. Retrieved from www.hud.gov/sites/documents/PIH2013-15HOMELESSQAS.PDF

HUD Exchange. (2018). Continuum of Care (CoC) Program Eligibility Requirements. Retrieved from www.hudexchange.info/programs/coc/coc-program-eligibility-requirements/

Kawulich, B.B. (2005). Participant Observation as a Data Collection Method. Forum: Qualitative Social Research, 6(2).

Keene, J. (2016). Community Plan to End Homelessness; Recommendation to Council to Adopt two Resolutions: (a) Endorsing the Community Plan to end Homelessness in 2015-2020; and (b) Supporting City Programs to Encourage and Fund Affordable Housing as Urged by the Santa Clara County Housing Task Force. City of Palo Alto City Council Staff Report. Retrieved from https://www.cityofpaloalto.org/civicax/filebank/documents/52172

Keuroghlia, A.S., Shtasel, D., \& Bassuk, E.L. (2014). Out on the Street: A Public Health and Policy Agenda for Lesbian, Gay, Bisexual, and Transgender Youth Who Are Homeless. American Journal of Orthopsychiatry, 84(1), 66-72.

Kresky-Wolff, M., Larson, M.J., O'Brien, R.W., McGraw, S.A. (2010). Supportive Housing Approaches in the Collaborative Initiative to Help End Chronic Homelessness (CICH). Journal of Behavioral Health Services \& Research, 37(2), 213-225.

LifeMoves. (2018). Our Services. Retrieved from www.lifemoves.org/our-solution-works/our-services /

Ly, A. \& Latimer, E. (2015). Housing First Impact on Costs and Associated Cost Offsets: A Review of the Literature. The Canadian Journal of Psychiatry, 60(11), 475-487. 
Loving, J. (2018). Harnessing the Power of Collective Impact to End Homelessness. United States Interagency Council on Homelessness. Retrieved from www.usich.gov/news/harnessing-the-power-of-collective-impact-to-end-homelessness

Massey, D. S., \& Denton, N. A. (1993). American apartheid: Segregation and the making of the underclass. Cambridge, MA: Harvard University Press.

McKenna, S. (2016). Criminalizing Homelessness is a Public Health Issue. The Establishment. Retrieved from

www.theestablishment.co/criminalizing-homelessness-is-a-public-health-crisis-c 1a74611 $898 \mathrm{e}$

Morales-Ferrand, J. (2016). Memorandum: Update on Homeless Housing Initiatives.

Retrieved from www.sanjose.granicus.com/MetaViewer.php?meta_id=582012

National Coalition for the Homeless. (2012). Multiple Factors Contribute to

Homelessness. Homelessness, edited by Tamara Thompson, Greenhaven Press, 2012.

National Coalition for the Homeless. (2014). Homelessness in America. Retrieved from www.nationalhomeless.org/about-homelessness

National Coalition for the Homeless. (2006). McKinney- Vento Act Fact Sheet. Retrieved from www.nationalhomeless.org/publications/facts/McKinney.pdf

National Law Center on Homelessness and Poverty. (2014). No Safe Place: The Criminalization of Homelessness in U.S. Cities. Retrieved from www.nlchp.org/documents/No_Safe_Place

O'Flaherty, B. (1996). Making room: The economics of homelessness. Cambridge, MA: Harvard University Press.

Office of Supportive Housing. (2018). Urban County of Santa Clara Draft Amended FY17/18 Annual Action Plan.

www.sccgov.org/sites/osh/HousingandCommunityDevelopment/UrbanCountyProgram/D ocuments/FY 18\%20DRAFT\%201st\%20Amended\%20Annual\%20Action\%20Plan.pdf

Pathway Society. (2014). Transitional Housing. Retrieved from www.pathwaysociety.org/home-page/treatment-options/transitional-housing-2/ 
Quigley, J.M., Raphael, S. (2001). The Economics of Homelessness: The Evidence from North America. European Journal of Housing Policy, 1(3), 323-336.

Rickards, L.D., McGraw, S.S., Araki, L., Casey, R.J., High, C.W., Hombs, M.E., \& Raysor, R.S. (2010). Collaborative Initiative to Help End Chronic Homelessness: Introduction. Journal of Behavioral Health Services \& Research, 37(2), 149-166.

Roberts, C. (2016). The Great Eliminator: How Ronald Reagan Made Homelessness Permanent. SF Weekly.

www.sfweekly.com/news/the-great-eliminator-how-ronald-reagan-made-homelessness-p ermanent/

Salvation Army. (no date). Emmanuel House. Retrieved from www.emmanuelhouse.salvationarmy.org/

Shepard, M. (1997). Site-Based Services for Residents of Single-Room Occupancy Hotels. Social Work, (42)6, 585-592.

Sylvia, R.D. \& Sylvia, K.M. (2012). Program Planning and Evaluation for the Public Manager. Waveland Press Inc. Kindle Edition.

Thomas, A. (2017). The Demographics of Poverty in Santa Clara County. New Geography. www.newgeography.com/content/005501-the-demographics-poverty-santa-clara-county

Thompson, L. (2006). A History of HUD. Retrieved from https://monarchhousing.org/wp-content/uploads/2007/03/hud-history.pdf

Thompson, M. (2015). Law Enforcement is a Critical Component of the Coordinated Effort to End Homelessness. Community Oriented Policing Services, U.S. Department of Justice, (8)11. Retrieved from

https://www.americanbar.org/content/dam/aba/images/homelessness_poverty/Dispatch-1 2-2015_LawEnforcement\%20Homeless\%20v2.pdf

Thompson, T. (2012). Opposing Viewpoints. Opposing Viewpoints in Context. National Coalition for the Homeless. Originally Published as "Why are People Homeless? NCH Factsheet, 2009." Retrieved from http://ink.galegroup.com/apps/doc/EJ3010812211/OVIC?u=oak30216\&xid=f15f691c 
Wegmann, J. and Christensen, K.. (2016). Subsidized Rental Housing in the United States: What We Know and What We Need to Learn in Three Themes. Planning Forum (17), 55-73.

Why Some Homeless Choose The Streets Over Shelters. Talk of the Nation. National

Public Radio NPR, December 6 2012. Radio. Retrieved from

https://www.npr.org/2012/12/06/166666265/why-some-homeless-choose-the-streets-over -shelters 